\title{
THE PLIGHT OF HUMANITY IN PAUL
}

\author{
SANG BOO* \\ Golden Gate Baptist Theological Seminary
}

\begin{abstract}
In Paul and Palestinian Judaism, E. P. Sanders argues that, for Paul, humanity's plight was not the condition that necessitated the solution of Jesus Christ. Instead, the solution was presented to Paul first on the Damascus road, and humanity's plight was simply the logical corollary to the solution. This study will critically examine the particulars of Sanders's argument-particularly with regard to Romans 7, Philippians 3, and Galatians 3-and offer some alternative exegetical analyses. This essay will argue that, while the development of Paul's thinking may indeed have run from solution to plight, the exposition of Paul's thinking goes from plight to solution. The movement of Paul's exposition may suggest that his conception of the plight of humanity was born out of his ideational milieu, which must have been fed, at least, by the Old Testament and evidenced, at least, by literature such as 4 Ezra.
\end{abstract}

KEY WORDS: New perspective, plight of humanity, Romans 7:14-25, Philippians 3:4-14, Galatians $3: 1-14,4$ Ezra

\section{Introduction}

It would be coy to talk about the "The Plight of Humanity in Paul" without talking about E. P. Sanders. In Paul and Palestinian Judaism, Sanders makes a claim that "Paul's thought did not run from plight to solution, but rather from solution to plight". ${ }^{1}$ Sanders argues that, for Paul, humanity's plight was not the condition that necessitated the solution. Rather, humanity's plight was the logical corollary of the solution. This study will examine the particulars of Sanders's understanding of the "solution to plight" in Paul, and offer some alternative exegetical analyses along the way. While the development of Paul's thinking may indeed have run from solution to plight, the exposition of Paul's thinking goes from plight to solution, which might sug-

* SANG BOO is a PhD candidate at Golden Gate Baptist Theological Seminary in Mill Valley, California, USA, where he also received his Master of Divinity in 2009.

1 E. P. Sanders, Paul and Palestinian Judaism. A Comparison of Patterns of Religion, First American Edition (Philadelphia, PA: Fortress Press, 1977), 443.

(C) EMANUEL UNIVERSITY of ORADEA

PERICHORESIS $10.2(2012)$ 
gest that Paul's conception of the plight of humanity was born out of the ideational milieu in the world of Paul.

\section{Solution to Plight is Born}

Sanders's observation that Paul's thinking runs from solution to plight is basically a dialectical response to Rudolf Bultmann. Commenting on Bultmann's Theology of the New Testament, ${ }^{2}$ Sanders introduces his major section on "The law, the human plight and the relationship of the solutions to it" saying, "It is perhaps the principal fault in Bultmann's treatment of Paul that he proceeded from plight to solution and supposed that Paul proceeded in the same way. On page after page of Bultmann's discussion of Paul's conception of 'man prior to faith' I have marked 'backwards". ${ }^{3}$ Bultmann's choice to proceed from plight to solution stems from his "decision to start with anthropology and to consider first man without faith, ... and this starting point coheres with understanding 'righteousness by faith' as the central theological theme and with focusing the discussion on the individual rather than on the eschatological, cosmic and participationist features of Paul's thought". ${ }^{4}$

Sanders rejects righteousness by faith as being the center of Paul's theology. He generally follows Albert Schweitzer's argument that righteousness by faith is not an independent concept for Paul, but appears only in polemical arguments concerning circumcision. ${ }^{5}$ Furthermore, Paul never connects righteousness by faith with any of the other benefits of salvation, like resurrection and possession of the Spirit. Finally, Paul provides no correlation between righteousness by faith and good works (ethics). Instead, Schweitzer found that all of these benefits of salvation, as well as the ethical outworkings of salvation, are best explained by the doctrine of mystical union, that is, the Pauline language of being in Christ.

Sanders does not propose a particular "center" for Paul's theology, except to discount righteousness by faith as that center. However, he proceeds forward by identifying two "primary convictions which governed Paul's Christian life: (1) that Jesus Christ is Lord, that in him God has provided 
for the salvation of all who believe (in the general sense of 'be converted'), and that he will soon return to bring all things to an end; (2) that he, Paul, was called to be the apostle to the Gentiles". ${ }^{6}$

\section{Where's the Beef?}

Logically, a problem must precede a solution, because a solution infers a problem that needs to be solved. The solution, according to Sanders, is that "God has provided for salvation in Christ". ${ }^{7}$ This solution infers some plight that humanity needs to be saved from. By suggesting that the solution is prior, Sanders is suggesting that Paul was not aware of any plight before his encounter with Jesus. ${ }^{8}$ Sanders comes to this conclusion primarily based upon his reading of Romans 7, Philippians 3, and Galatians 3. We will want to look very closely at his exposition of these passages. However, no detailed exposition is forthcoming.

Despite the significance of Sanders's claim that the solution comes before the plight in Paul's thinking, his exegesis on the relevant passages is quite cursory. The whole thrust of his exegesis may be found on one page, 443 . His argument basically rests upon the repudiation of the autobiographical reading of the tormented "I" in Romans 7:7-25. In this passage, Paul employs a rhetorical "I" to express how the Law exacerbates a person's inclination towards sin. Debate over this passage concerns the degree to which the "I" reflects Paul's personal experience under the Law. If this "I" is not Paul, then it seems abundantly clear to Sanders that "Paul did not, while "under the Law', perceive himself to have a 'plight' from which he needed salvation". ${ }^{9}$ Therefore, the necessity of a solution-the reality of a human plight-became evident to Paul only after the solution presented itself in his encounter with Jesus on the Damascus road, but not before.

Sanders's argument loses steam, because he does not clearly demonstrate that the "I" in Romans 7 is not Paul. Instead, he simply says, "The attempts to argue that Romans 7 shows the frustration which Paul felt during his life as a practicing Jew have now mostly been given up, and one may rightly and safely maintain that the chapter cannot be understood in

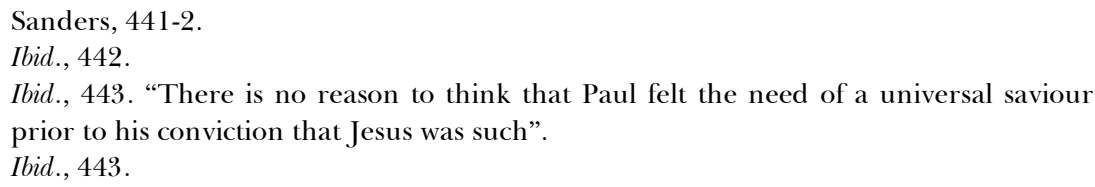


this way", then refers to Philippians 3 for proof. ${ }^{10}$ In Philippians 3, Paul confidently asserts about himself that he is, "as to the righteousness which is in the Law, found blameless" (3:6b). But Sanders does not really demonstrate how the Philippians passage proves the point. Instead, he refers to the work of other scholars in a footnote. His most assertive statement of proof is found there, as well:

The following points seem to me decisive [italics mine] in favour of the position followed here: (1) Galatians 3.11f., by repudiating the law on the grounds of Christology and soteriology, rather than because of its supposed unfulfillability, supports the view of Philippians 3 that Paul had no trouble fulfilling the law satisfactorily. It is most important that Paul's argument concerning the law does not in fact rest on man's inability to fulfill it (below, $478 \mathrm{f}$ and n. 23; 483-5). (2) The entire argument of Romans 6-8, in which Paul contrasts life in Christ with life under the law, indicates that Romans 7 should be read in the same light. The fact that Paul can express the pathos of life under the law as seen through Christian eyes does not mean that he had himself experienced frustration with the law before his own conversion. ${ }^{11}$

These points are relevant, but hardly decisive. Rather, Sanders seems to take it for granted that the Romans 7 and Philippians 3 passages are contradictory, and that the Philippians passage, rather than the Romans passage, is the statement that accurately reflects Paul's life. We will want to consider the Romans, Philippians, and Galatians passages ourselves to measure the strength of Sanders's claim that, for Paul, the solution preceded the plight—first, Romans and Philippians, and then Galatians.

\section{Romans 7 versus Philippians 3}

Considering Romans 7, Sanders is surely right when he says that the passage should be viewed in light of the contrast between life in Christ and life under the law. That is, indeed, the function of the passage, as Dunn points out, as well. ${ }^{12}$ Furthermore, it would be pointless to argue against the consensus that sees the passage as an elaboration of a generic person under the bondage of the Law. ${ }^{13}$ The question is, however, how intimately did Paul

Ibid., 443 .

Ibid., 443 n. 4.

James D. G. Dunn, The Theology of Paul the Apostle (Grand Rapids, MI: Eerdmans, 1998), 472 n. 55

13

Ibid., 472 n. 56.

PERICHORESIS 10.2 (2012) 
relate to this "hypothetical" person? Strictly speaking, Sanders is also right when he says that Paul's elaboration does not implicate himself. However, Sanders cannot insist that Paul excludes himself from the collective tormented "I". There is no clear logical basis for it. Within scholarship, there may even be a trend toward respecting the personal nature of Paul's expression, even if he is speaking rhetorically. James Dunn observes, "None of this, it has to be said, reads like the description of a state or experience which is now wholly past for the writer. The existential anguish of 7:14-24 sounds like an experience Paul knew only too well". ${ }^{14}$

Sanders tries to support a purely rhetorical understanding of the "I" by pointing to Philippians 3, but this move does not hold to reason. In this passage, it is important to note that the "righteousness which is in the Law" (verse 6) is the same as "a righteousness of my own derived from the Law" (verse 9a). However, this "righteousness" is definitely not the same as "the [saving] righteousness which comes from God on the basis of faith" (verse 9c). In fact, they are antithetical. The antithetical understanding of the same word provides a strong clue that Paul is speaking ironically. A Law-derived righteousness - the righteousness of which Paul is found blamelesscorresponds, in fact, to the arrogant "confidence in the flesh" that Paul speaks about in verses 2-6. His point is that he has far more right to be confident than any of the "dogs", "evil workers", and "false circumcision" (verse $1)$.

The irony of Paul's statements here is brought to the surface by the assumption that no one can adequately fulfill the Law. Given this assumption, Paul is not straightly asserting his righteousness under the Law. Rather, the boasting that he does in verses 4-6 is a mockery of the boasting that comes with a law-derived righteousness. In other words, if there was any objective measurement of righteousness with respect to the Law, Paul is saying that he has a greater right to be arrogant-or more arrogant (objectively!). If Sanders and others can read the tortured "I" of Romans 7 as a generic portrait of "the pre-Christian or non-Christian life as seen from the perspective of faith", ${ }^{15}$ then it is no far leap to read the confident "I" of Philippians 3 in the same kind of way. In fact, given the assumption of the unfulfillability of 
the complete requirements of the Law, both passages become normalized to a consistent portrayal of the person Paul. That is, the plight bridges the rhetoric and the reality of both passages.

Thus, it would seem that Sanders over-emphasizes the rhetorical nature of the "I" in Romans 7 but under-emphasizes the rhetorical nature of the "I" in Philippians 3. Now, Sanders clearly recognizes that the key to his claim is to demonstrate that Paul did not consider the Law as being unfulfillable. The exclamation point of his argument is the claim that Galatians 3:11ff repudiates the Law based on Christology and soteriology, not unfulfillability. Further examination of this section of the letter will show that this claim, also, does not hold to reason.

\section{Galatians 3}

In Galatians 3:1-14, Paul's main point is summarized by the earlier claim that "a man is not justified by the works of the Law but through faith in Christ Jesus" (2:16). It is clear enough that Paul was engaging in a polemiccal argument against the teachings of some Jewish Christians who had insisted to the Galatian church that they must adhere to certain aspects of the Law-circumcision (5:2) and, perhaps, Jewish feast days (4:10), at least. ${ }^{16}$ So basically, Paul directs his attack at a perspective that sees adherence to the Law as being necessary in order to have a share in the covenant blessing of God-a perspective encapsulated by the phrase "by works of the Law" (ex ergōn nomou).

Paul presents his argument in four stages. In the first stage, Paul appeals to the experience of the believers with respect to how they received their salvation.

\footnotetext{
${ }^{1}$ You foolish Galatians, who has bewitched you, before whose eyes Jesus Christ was publicly portrayed as crucified?

${ }^{2}$ This is the only thing I want to find out from you: did you receive the Spirit by the works of the Law, or by hearing with faith?

${ }^{3}$ Are you so foolish? Having begun by the Spirit, are you now being perfected by the flesh?

${ }^{4}$ Did you suffer so many things in vain-if indeed it was in vain?

${ }^{5}$ So then, does He who provides you with the Spirit and works miracles among you, do it by the works of the Law, or by hearing with faith?
}

16 Ben Witherington III, Grace in Galatia. A Commentary on St. Paul's Letter to the Galatians (Grand Rapids, MI: W. B. Eerdmans, 1998), 23-24.

PERICHORESIS 10.2 (2012) 
Their experience of salvation began with the hearing of Paul's gospel, to which they responded with faith. Consequently, they received the Spirit and manifested miracles as evidence of the presence of the Spirit. Their point of reference is the receiving of the Spirit (verses 2, 3, 5) and the miracles that were manifested (verse 5). From that point of reference, they should be able to judge whether their salvation came from "hearing with faith" or "works of the Law". The rhetorical questioning makes it clear that they received the Spirit by hearing with faith. The questions are rhetorical, because the answer should be self-evident based upon their own experience.

In this first stage, Paul establishes the antithesis between "works of the Law" and "hearing by faith". ${ }^{17}$ Two additional points are noteworthy here. First, "works of the Law" is the element that intrudes into the salvation experience of the Galatian believers. The notion of "works of the Law" within their context would have been unknown, unless someone had introduced it after their initial salvation experience. That is to say, repudiating "works of the Law" is the greater focus of Paul's polemic. This is significant in that the emphasis is placed on humanity's negative relationship to the Law, which Paul picks up later. Second, Paul launches this argument from the image of the death of Jesus, not his resurrection. It may be that Paul is simply playing to the pathos of Jesus' death (verses 2:20-21). However, this image also accentuates the point that believers have been "crucified with Christ" (verse 2:20). A believer's participation in the death of Christ carries with it the sense of participation in God's judgment against sin through Christ. ${ }^{18}$ In other words, by highlighting the image of Jesus' death, Paul is foregrounding the reality of the human condition of sin and the drastic measures God had to undertake to resolve it.

In the second stage of Paul's argument, he places the Galatian experience of salvation within the larger framework of salvation history.

${ }^{6}$ Even so Abraham BELIEVED GOD, AND IT WAS RECKONED TO HIM AS RIGHTEOUSNESS.

${ }^{7}$ Therefore, be sure that it is those who are of faith who are sons of Abraham. here.

18 Dunn, Paul, 410: "Participation in Christ always included participation in his death;" 210: "... Jesus' death is the death of all humanity;" 211: "The death of the one signifies that there is no way out for weak and corrupted flesh except through death..." especially, 223: “... those who identified with Christ in his death were saved from dying their own death as the outcome of their subservience to sin". 
8 The Scripture, foreseeing that God would justify the Gentiles by faith, preached the gospel beforehand to Abraham, saying, "ALL THE NATIONS WILL BE BLESSED IN YOU".

${ }^{9}$ So then those who are of faith are blessed with Abraham, the believer.

Paul is introducing the concept of covenant inheritance. It is likely that Paul raises this issue, because his opponents raised this same issue. ${ }^{19}$ Who are the sons of Abraham, and who will inherit the promises made to Abraham? Paul establishes Abraham as an exemplar of faith, one who "believed God". At the same time, Paul makes the correlation between the Galatians, who "heard with faith", and Abraham, who also heard the gospel with faith. Those Galatians who had heard with faith (verses 2, 5) are "those who are of faith" (verses 7, 9). They are to "be sure" (ginōskete, "know", "understand") that they are among those who are counted as sons of Abraham. So as sons of Abraham, who are "of faith", they too will be reckoned as righteous by God and, consequently, have a share in the gospel that was communicated to Abraham, the promise of God's blessing to all the nations. In other words, everyone is the same with respect to God's great plan of salvation. All have access to the promised blessing of God.

For the purposes of this study, this is significant for what follows, but also for something that precedes. The preliminaries of Paul's argument actually begin at verse 2:15: "We are Jews by nature and not sinners from among the Gentiles". He says this after the recounting of his conflict with Peter at Antioch. It would seem that Paul is pointing out that Gentiles are by nature sinners, whereas Jews are by nature not. Then he proceeds in verse 16, "nevertheless knowing that a man is not justified by the works of the Law but through faith in Christ Jesus, even we have believed in Christ Jesus". It is likely that Paul was being ironic in characterizing Gentiles as sinners and Jews as not (Romans 3:23). In light of this irony, and especially in the context of the "hypocrisy" of Peter, Barnabas, and others, Paul is emphasizing that the Jews are indeed sinners too. There is absolutely no anthropological difference at all between Jews and Gentiles, and the condition of the Jews is the same as the condition of the Gentiles-that of sinner. ments or assertions in Paul's letters and assuming that Paul's adversaries were arguing just the opposite”. However, see 25 , where he says, “... it is also very believable that the agitators had used certain Scriptural arguments having to do with Abraham among other subjects to persuade the Galatians". 
This point is carried home in the third stage of Paul's argument, in which Paul expounds on the curse of the Law.

${ }^{10}$ For as many as are of the works of the Law are under a curse; for it is written, "CURSED IS EVERYONE WHO DOES NOT ABIDE BY ALL THINGS WRITTEN IN THE BOOK OF THE LAW, TO PERFORM THEM".

11 Now that no one is justified by the Law before God is evident; for, "THE RIGHTEOUS MAN SHALL LIVE BY FAITH".

${ }^{12}$ However, the Law is not of faith; on the contrary, "HE WHO PRACTICES THEM SHALL LIVE BY THEM".

The first stage of Paul's argument appeals to the experience of the Galatian believers in order to deny the validity of salvation through works of the Law. In the second stage, he locates their experience of salvation in the context of the Abrahamic covenant, completely outside the purview of the Law (not once is it mentioned). In all likelihood, Paul's opponents taught that the outward symbols of the covenant, particularly circumcision, were a necessary prerequisite for sharing in the Abrahamic covenant. Paul points out that God reckoned Abraham as righteous because he believed God's promise, not because of his obedience to God's command to circumcise. Abraham's obedience was simply a response born out of his faith. Faith is the prior and necessary component. What Paul wants to show in the third stage of his argument is why circumcision should not be considered a proper expression of the obedience of the faith for non-Jewish Christians, too. If Abraham is the exemplar of faith, why should not all sons of Abraham also follow his example of circumcision?

Paul's answer is that anyone who lives with an orientation toward life that is "by works of the Law" (ex ergōn nomou) is under a curse. He elaborates by citing Deuteronomy 27:26 (LXX): "CURSED IS EVERYONE WHO DOES NOT ABIDE BY ALL THINGS WRITTEN IN THE BOOK OF THE LAW, TO PERFORM THEM". If a person is cursed by not abiding in the entirety of the Law, and if a person is cursed by having an orientation toward life that is ex ergōn nomou, then it logically follows that it is impossible to "abide by all things written in the book of the Law". This demonstrates definitively that what Paul means by ex ergonn nomou is the notion that the Abrahamic blessing, the covenant inheritance that began with Abraham, is accessible by abiding by the Law, whether partially or totally. For Paul, this notion-whether in partial or total abiding-is absolutely mistaken, because Scripture attests to the necessity of complete obedience, and complete 
obedience is impossible. Those who seek to share in the blessing of Abraham from an orientation ex ergōn nomou find themselves at a logical impasse because of the unfulfillability of the entirety of the Law.

In verse 11, Paul restates his primary point that no one can be justified by the Law $(e n \text { nomōo })^{20}$ - that is, by abiding by the Law. His warrant is Scriptural, once again. Habakkuk 2:4 states unequivocally (it is dēlon for Paul, at least) that "THE RIGHTEOUS MAN SHALL LIVE BY FAITH". For Paul, the truth to which Habakkuk 2:4 attests-that the righteous person shall live by faith (ek pisteoss) — simply reemphasizes the point that a person is justified by faith and not by works of the Law (2:16).

One thing is for certain: verse 12 makes it very clear that the nature of the Law and the nature of faith are completely different. The Law is not "of faith" (ek pisteōs). In fact, the supposition that the Law is $e k$ pisteōs is in stark contrast (alla) to the truth to which Leviticus 18:5 attests-"HE WHO PRACTICES THEM SHALL LIVE BY THEM". Paul appropriates these two passages in such a way as to suggest a strong structural similarity: ho dikaios ek pisteōs zēesestai versus ho poiēsas auta zēsestai en autois. ${ }^{21}$ In the Leviticus passage, auta and autois refer to the tenets of the Law. Collectively, they simply make up the Law. The effect of Paul's rhetorical strategy here, particularly in light of the context of his argument, would seem to be to differentiate ho dikaios and ho poiessas auta- "the righteous one" versus "the one who does them" (i.e., the Law) -as well as to differentiate $e k$ pisteōs versus $e n$ autois_"by faith" versus "by them" (again, the Law). The difference between living by faith versus living by the Law is the difference between being righteous versus doing the Law. Righteousness has nothing to do with doing the Law. Or perhaps more in line with the flow of Paul's rhetoric in verse 12: the Law is not of faith; on the contrary, works of the Law have nothing to do with attaining righteousness, which is exclusively a matter of faith.

This point is developed further when we consider the full text of the Leviticus citation from the LXX: ${ }^{22}$ kai phulaxesthe panta ta prostagmata mou kai panta ta krimata mou kai poièsete auta, ha poiessas anthrōpos zēsestai en autois...

20 This theme is first expressed in verse 2:16, but the expression there is ex ergon nomou.

21 Moisés Silva, "Galatians", in Commentary on the New Testament Use of the Old Testament, ed. by G. K. Beale and D. A. Carson (Grand Rapids, MI: Baker Academic, 2007), 800-4. Silva notices the structural similarities, as well. Whether Paul modified his sources to suggest this similarity or whether this similarity was already present is uncertain. 
("and you shall keep all of My ordinances and all of My judgments and do them; the person who does them shall live by them... “, AT). Could it be that doing the Law has nothing to do with righteousness, because it is impossible to fulfill all of it? It would not be wise to insist that this is what Paul was doing, but it is certainly well within the realm of possibilities that Paul wanted to reinforce the notion of the unfulfillability of the entirety of the Law without making it his primary emphasis, which is justification by faith, not by the Law. If this is what Paul is doing, then by doing so, he elevates the point of the unfulfillability of the entirety of the Law in the overall argument.

In the fourth and final stage, Paul concludes his argument in verses 1314 by wrapping up all the major points from verses 1-12 together into a Christological and Soteriological statement.

${ }^{13}$ Christ redeemed us from the curse of the Law, having become a curse for usfor it is written, "Cursed is everyone who hangs on a tree"-

${ }^{14}$ in order that in Christ Jesus the blessing of Abraham might come to the Gentiles, so that we would receive the promise of the Spirit through faith.

Verse 13 begins with what many believe to be an early Jewish-Christian confessional statement. ${ }^{23}$ The phrase "curse of the Law" is used only here in Paul. This "curse" ties back to the "curse" of verse 10, which relates to the unfulfillability of the entirety of the Law (see above). Ben Witherington III does not speak of the "curse" as relating to some inevitable condition, the inherent nature of the Law, but rather to the reality of the situation. ${ }^{24}$ How-

Richard N. Longenecker, "Galatians”, ed. by David A. Hubbard and Glenn W. Barker, Word Biblical Commentary, vol. 41 (Dallas: Word, Incorporated, 2002), 121. "Also of note is the fact that the imagery of verse 13a is pregnant with meaning, though not spelled out: 'redemption' as a commercial metaphor used in a religious setting and ;becoming a curse for us' as language stemming from the sacrificial cultus. All of this, it seems, suggests that what we have here is a pre-Pauline, Jewish Christian confessional statement regarding Jesus' death as a redeeming and atoning self-sacrifice". See also, H. D. Betz, Galatians. A Commentary on Paul's Letter to the Churches in Galatia, Hermeneia (Philadelphia, PA: Fortress, 1979), 149-51. For an opposing view, see F. F. Bruce, The Epistle to the Galatians. A Commentary on the Greek Text (Grand Rapids, MI: W. B. Eerdmans, 1982), 166.

24 Witherington III, 238. "Paul is suggesting here, not that particular individuals might not keep the Law even in detail (cf. PhilIPIANS 3:6), but that the Jewish people as a people had not kept all the Law, indeed had repeatedly failed to do so, and so were under the curse of the Law. Accordingly, the Jewish people as a people were in need of redemption from the curse of the Law". 
ever, it should be noted that beginning in the third stage of Paul's argument, he seems to make a transition from a discussion about a particular human orientation towards the Law [ex ergōn nomou, verses 2:16 (3 times); $3: 2,5,10]$ to a discussion about the nature of the Law itself (en nomō, verse 11). It would be wise not to insist on this point either, but it does make sense in the context of Paul's discussion concerning the nature of the Law that follows in verses 15ff. Furthermore, Romans 5:12ff would seem to indicate that the inevitability of death is a direct manifestation of the inevitability of sin, a condition exacerbated when "The Law came in so that the transgression would increase" (Romans 5:20a).

The rest of the confessional statement in verse 13 talks about Christ "having become a curse for us". First, it should be noted that the citation of the Deuteronomy passage serves to delimit the meaning of this phrase as a reference to Christ's crucifixion. It may have been commonly understood that Jesus' having becoming a curse is a reference to his crucifixion, however it is not readily apparent by the phrase itself. The citation of Deuteronomy 21:23 makes that connection more or less explicit. ${ }^{25}$ The natural question that arises for readers today is: in what way does Christ redeem "us"which probably refers to Jewish-Christians ${ }^{26}$-from the curse of the Law by being hanged on a cross? ${ }^{27}$ Whether this question plagued the readers of

Ibid., 239. "Paul may also have known about the use of the text in early Judaism, for example in 11QTemple 64:6-13 where the language of this text is used to speak of execution on a tree, that is of crucifixion (so also 4Q169 psNah 1:17-18)". Also, Longenecker, 122; and Bruce, 165.

26 It is best to read the first-person plural pronouns as referring to Jewish-Christians, following Betz, 148, and Witherington, 237, contra Bruce, 166-7. Longenecker seems to have a mediating position. The reason for accepting the Jewish-Christian reference will become apparent later.

Betz, 150, believes, "Most likely, the statement is based upon a pre-Pauline interpretation of Jesus' death as a self-sacrifice and atonement (see also Galatians 1:4; 2:20). Due to Christ's incarnation (4:4-5) he suffered his death as a human being. Since he was free of $\sin$ (cf. 2 Corinthians 5:21), his death was, in Jewish terms, uniquely meritorious". Bruce, 166, says, "Christ had endured the curse on his people's behalf (by being 'hanged on a tree') in order to redeem them from the curse pronounced on those who failed to keep the law". Longenecker, 122, says, "For Jews, the proclamation of a crucified Messiah was scandalous... The process as to how early Christians came to understand Jesus as both Messiah and accursed may be obscure, but their conclusion is clear: the curse of the cross was 'an exchange curse' wherein Christ became a curse for us". But he also looks at this statement in terms of its functionality, saying that Paul cites this confession "to show how Christ's bearing of mankind's curse nullifies all thoughts of legalism and to set up his conclusion regarding the blessing of Abraham and the promise of the Spirit in verse 14". On the other hand, Witherington, 239, says, "There 
Paul's time is not clear. Paul certainly had an idea of the answer to this question, although his writings demonstrate a complex of meaning. In the current verse, all that is clear is that Christ, by his dying on the cross, somehow released Jewish-Christians from the curse of the Law. From the preceding discussion, it is likely-and perhaps probable-that the curse of the Law is related to the logical dilemma of the unfulfillability of the Law, because the unfulfillability of the Law effectively and completely blocks access to the covenant blessing of God promised to Abraham. Despite the humanly logical gap that exists with regard to Christ being cursed in order to resolve the curse of the Law, the point to note is that such a resolution was necessary in order for God's promise to be fulfilled (especially, Roman 15:8).

When Paul came to this realization is not as significant as the reality of this realization for Paul. As mentioned earlier, it needs to be taken seriously that the tormented "I" of Romans 7:14-25 reflects Paul's own personal experience. However, Paul's intention in this passage to represent the whole of Israel (synecdoche) must also be taken seriously. It would also be a mistake to suppose that Paul had no inkling of this condition before his encounter with Jesus, contra Sanders. ${ }^{28}$ To suppose that Paul had no idea concerning this matter contradicts the evidence of the complexity and creativity of Paul's mind that is found in his letters. Furthermore, it is clear that this idea of the covenant endangered by the unfulfillability of the Law did not materialize in a vacuum. It was a part of Paul's ideational milieu.

For Paul, the restoration of access to the covenant promise of God made to Abraham is the goal. The Law, by its nature as a curse, blocks access to the covenant inheritance, not only to the Jews, but to the Gentiles, as well. Verse 14 completes the salvation historical picture with the offering of the "blessing of Abraham" to the Gentiles, "so that we would receive the promise of the Spirit through faith". Here, the first-person plural pronoun now includes both Jews and Gentiles.

Taken together, verses 13-14 make the point that Jesus was crucified for the Jews to free them from the "curse of the Law", so that the whole world would have access to the blessing of Abraham. ${ }^{29}$ This is in line with Paul's

is no need to talk about the exchange of one curse for another, rather we must talk about the exchange of one object of the curse for another. Christ was born under the Law, and endured the curse that fell on Lawbreakers, not because Paul thinks he was such, but on behalf of those who were".

28 Sanders, 443.

29 Dunn, Paul, 161, states elegantly, "In thus giving the law, God seems to have surrendered it to the power of sin and death, since sin uses and abuses the law to bring about 
thinking that salvation would come first to the Jews and then to the Gentiles (Romans 1:16). That being the case, it would be foolish to regress and live $e x$ ergōn nomou, under the curse of the Law once again. The Deuteronomy passage cited in verse 13 helps to shape this understanding. Besides the obvious reference to Jesus' crucifixion, the point of the passage would seem to be to not prolong the "curse" of the person that is hung on the tree. ${ }^{30}$ In the same way, Paul seems to be saying to the Galatians not to prolong the curse of the Law, since Jesus has dealt with it once and for all. The sense that Paul conveys in this argument is that the blessing of God, as given in the Abrahamic covenant, is something that was intended to be available to everyone. Paul understands this blessing to be the promise of the Spirit that is only accessible through reckoned righteousness-the Spirit that the Galatian believers received and experienced. Abraham, as exemplar, demonstrated that access to this righteousness is by faith. On the other hand, an orientation toward the Law that sees Torah obedience as the means of attaining the covenant inheritance is inherently flawed, because the nature of the relationship between humanity and the Law is the doing of the entirety of the Law, which Paul logically suggests leads to the curse of the Law. Access to the covenant promise of Abraham is not possible through the Law, because complete Torah obedience is impossible; the Law is unfulfillable in its entirety.

\section{The Plight in Paul's Ideational Milieu}

So Sanders is correct in saying that Paul is "repudiating the law on the grounds of Christology and soteriology" ${ }^{31} \mathrm{He}$ is probably also correct in saying, "There is no reason to think that Paul felt the need of a universal saviour prior to his conviction that Jesus was such". ${ }^{32}$ But if Sanders means by this that Paul had no sense of the unfulfillability of the Law, no sense of the utter depravity of the human condition, then he is extending the limits of

death. But at a deeper level God's purpose may have been to bind sin to death and thus to exhaust the power of sin in death. It may appear to be the tragedy of the law that it condemns sin and sinner to death. But it may also be the triumph of the law that it transforms death from a final judgment on the sinner to the final destruction of sin itself".

30 F. F. Bruce, 164. "The exposure of a criminal's corpse on a tree or pole, then, was not to be prolonged beyond sundown: such continued exposure was an affront not only to human decency but to God himself (Hebrew qilelat "lōhîm could mean 'affront to God' rather than 'accursed by God', although the LXX chooses the latter rendering)".

31 Sanders, 443, n. 4.

32 Ibid., 443.

PERICHORESIS 10.2 (2012) 
common sense. It is more likely that Paul embarked on his repudiation of the Law under the assumption that, in its essence, the Law is unfulfillable due to the human condition of sin. Whether such an assumption was developed in any way in Paul's thinking is irrelevant. When the solution to the plight of humanity came into his consciousness after his encounter with Jesus, the idea of the plight was definitely already embedded within the solution and probably already embedded within Paul's cultural psyche, as well.

Part of the problem with Sanders's thesis regarding the human plight has to do with how the question presented itself to him. As mentioned earlier, it was formed out of his critique of Bultmann. Sanders objects to Bultmann's observation that "[Paul] does not first present the salvation occurrence... Instead he begins by exposing the plight of mankind, so that then the proclamation of God's salvation-deed becomes a decision-question". ${ }^{33}$ This observation is so obvious that the significance of it may be easily overlooked. In his engagement with Bultmann (and others), Sanders fails to ask a key question with respect to Paul's understanding of the human plight: why did Paul begin his argument with it in Romans? In fact, this question becomes even more intriguing if we accept Sanders's claim that Paul's thought moves from solution to plight.

The assumption of a plight in Paul's thinking did not materialize in a vacuum. It must have been born out of Paul's ideational milieu. Given his history-of-religions approach, Sanders would not disagree. Even so, Sanders finds that the soteriological concepts of original sin and universal sin are missing in most forms of Judaism. ${ }^{34}$ This statement is curious, and it seems explicable only on the basis of how Sanders delimited the scope of his primary sources.

Sanders considers Jewish literature between 200 BC-AD 200, with a few restrictions. There are three observations to make concerning the scope of Sanders's sources. First, his date range immediately excludes any of the Old Testament. The reason for this is obvious: Sanders did not set out to publish a survey of the entire corpus of ancient Jewish literature. But the degree to which he disregards the Old Testament in his analysis of Paul's pattern of religion is striking. The second observation is that he excludes any Hellenistic influences. He recognizes the strain that this imposes upon his methodology, so he devotes a whole section to this question in his con- 
clusion. ${ }^{35}$ The third observation, perhaps the one most crucial for the purposes of this study, is that Sanders analyzes 4 Ezra, but explicitly brackets it out as being unrepresentative of Judaism during Paul's life. ${ }^{36}$ In this section, we will briefly consider the first two restrictions, but examine 4 Ezra in a little more detail.

The Old Testament contains many examples that suggest the human proclivity toward sin. Of course, "original sin" and "universal sin" are systematic categories that are not expressly found in the Old Testament. However, "sin" is obviously a biblical category, and there are expressions of revelation about sin, especially in the Psalms, that could easily fit into the categories of "universal" and even "original". Just a few examples will suffice.

3 For I know my transgressions,

And my sin is ever before me.

4 Against You, You only, I have sinned

And done what is evil in Your sight,

So that You are justified when You speak

And blameless when You judge.

5 Behold, I was brought forth in iniquity,

And in sin my mother conceived me. (Psalm 51:3-5)

2 God has looked down from heaven upon the sons of men

To see if there is anyone who understands,

Who seeks after God.

3 Every one of them has turned aside; together they have become corrupt;

There is no one who does good, not even one. (Psalm 53:2-3)

9 "The heart is more deceitful than all else

And is desperately sick;

Who can understand it? (Jeremiah 17:9)

The point is not to suggest that these passages absolutely demonstrate categories of universal or original sin in the Old Testament, but that there is Scripture that would support theologizing in this direction. Surely Paul had read them.

$35 \quad$ Ibid., $552 \mathrm{ff}$.

$36 \quad$ Ibid., 428.

PERICHORESIS 10.2 (2012) 
Regarding Hellenistic influences, Sanders comments,

The question can perhaps best be put by focusing on Paul's conception of man's plight. The notion of enslavement, bondage, immediately suggests the possibility of a Hellenistic origin. It is this point which has served as a major dement in the comparison drawn between Paul and Philo by Goodenough and Sandmel. Thus Sandmel has argued that Paul's approach to the human predicament was Hellenistic, and this is his description of the Greek view: To the Greeks, the world was a place of sorrows, man was an unhappy mixture of the soul, which was spirit and good, and of the body, which was material and evil; and life was a burden. The goal of Greek religion, indeed, its leitmotif, was that of escape: escape from the inevitable end, death, escape from bondage to the body. ${ }^{37}$

Sanders rightly notes that the differences between Paul and Hellenistic thought precludes direct influence on his theologizing. But would it be so far-fetched to assume that Paul had at least read Philo (c. 20 BC-AD 45)?

The book of 4 Ezra (2 Esdras 3-14) is particularly relevant to this discussion. As mentioned earlier, Sanders questions whether 4 Ezra is representative of Pharisaism or Judaism during Paul's time. ${ }^{38}$ One of his key complaints is that 4 Ezra stresses a salvation by works of Law that is uncharacteristic anywhere else in Judaism. It should be noted that "salvation" here means the gift of covenant inheritance, symbolized by a New Jerusalem. Undoubtedly, this is a major theme in 4 Ezra, but the very uncompromising nature of this point brings to the surface an even larger issue: the apparent arbitrariness of God in the context of the universal nature of sin. This issue is left unresolved in 4 Ezra, and it is left unresolved in a very traditional kind of way: it is God's judgment, so who are you to question?

Four Ezra is composed of a series of dialogues between an apocalyptic prophet Salathiel (Ezra) and the angel of God, Uriel. It begins by giving a

Ibid., 427-8. His reasons for skepticism include (1) it was written after the fall of Jerusalem in 70, in fact, in response to that fall; (2) the pessimism that is characteristic of Paul is corrected in the concluding vision; and (3) 2 Baruch, which Sanders assumes uses 4 Ezra, stresses restoration and redemption. Sanders concludes, "The pessimism of the dialogues, where the doctrine of salvation by works is expressed, seems not to have been compatible with the view generally held in the Jewish community... In the entire body of surviving Jewish literature, the view that transgression necessarily leads to destruction and the equation of loyalty with absolute obedience are unparalleled. Thus IV Ezra has to be bracketed as representing a minority view, and a view which does not seem to have existed at all before the destruction". 
biblical account of a pattern of human transgressions whereby God establishes a relationship with a person and sets boundaries of behavior, but humanity persistently violates God's moral will. This pattern culminates with the giving of the Law. Then the protagonist, Salathiel, says (verses 3:20-22), "Yet you did not take away their evil heart from them, so that your law might produce fruit in them. For the first Adam, burdened with an evil heart, transgressed and was overcome, as were also all who were descended from him. Thus the disease became permanent; the law was in the hearts of the people along with the evil root; but what was good departed, and the evil remained". ${ }^{39}$ This observation sets the stage for the rest of the dialogues between Salathiel and the angel Uriel.

Salathiel continues to describe the pattern in David and the building of Zion, then he begins to question God's covenant loyalty. He asks, "[Has] another nation known you besides Israel? Or what tribes have so believed the covenants as these tribes of Jacob?... You may indeed find individuals who have kept your commandments, but nations you will not find" (verses 3:32-33). The angel Uriel, who is sent to answer him, says, "For a grain of evil seed was sown in Adam's heart from the beginning, and how much ungodliness it has produced until now-and will produce until the time of threshing comes!" (v. 4:30) In a subsequent vision, Uriel elaborates on God's plan for Israel: "For I made the world for their sake, and when Adam transgressed my statutes, what had been made was judged. And so the entrances of this world were made narrow and sorrowful and toilsome; they are few and evil, full of dangers and involved in great hardships" (verses 7:11-12). Later, Salathiel asks that God hear his intercession for those who have transgressed the strict requirements of the Law: "Blessed are those who are alive and keep your commandments! But what of those for whom I prayed? For who among the living is there that has not sinned, or who is there among mortals that has not transgressed your covenant? And now I see that the world to come will bring delight to few, but torments to many. For an evil heart has grown up in us, which has alienated us from God, and has brought us into corruption and the ways of death, and has shown us the paths of perdition and removed us far from life-and that not merely for a few but for almost all who have been created" (verses 7:45b-48). In response, Uriel says, “... I will rejoice over the few who shall be saved, because it is they who have made my glory to prevail now, and through them my name has now been honored. I will not grieve over the great number of 
those who perish..." (7:60b-61a) Uriel goes on to affirm that God's judgment had been "foreordained" from the beginning, and yet "those who live on earth shall be tormented, because though they had understanding, they committed iniquity; and though they received the commandments, they did not keep them; and though they obtained the law, they dealt unfaithfully with what they received" (verse 7:72). In fact, the reward of God's favor is given in the afterlife to those who have kept the law of God "perfectly" (verse 7:89).

In one respect, the dialogues may be understood as Salathiel trying to obtain a revelation of his own disposition from Uriel, and Uriel eventually does give him comfort by revealing God's favorable disposition towards him (7:76-77). However, Salathiel's very inquiry means that he is completely unsure of his own fate. He considers himself counted as one who has sinned against God, according to the precepts of the law, "For in truth there is no one among those who have been born who has not acted wickedly; among those who have existed there is no one who has not done wrong" (8:35). Salathiel recognizes that this is the very basis of God's grace (8:36), however the means of it is certainly not the law. There is some threshold of Torah obedience that Salathiel is trying to comprehend as the dividing line between salvation and perdition, but the answer is not at all forthcoming.

The contradiction compels Salathiel to say, "it would have been better if the earth had not produced Adam, or else, when it had produced him, had restrained him from sinning... O Adam, what have you done? For though it was you who sinned, the fall was not yours but ours also who are your descendants" (7:116/46b, 118/48). And Uriel continues to answer by affirming the principle of retribution-that those who fail to obey will be punished, and those who persevere in obedience will attain their heavenly reward.

The relevance of 4 Ezra to the discussion at hand is obvious. It contains themes strongly related to original sin, universal sin, the unfulfillability of the Law, works of the Law, covenant inheritance, strict retribution, and the necessity of God's grace-arbitrary though it be-all of which is left dangling in an unresolved Wisdom-like "because God says so". So when Sanders says, "In the entire body of surviving Jewish literature, the view that transgression necessarily leads to destruction and the equation of loyalty with absolute obedience are unparalleled, " he is not really correct. He forgets that Paul, too, was a Jew, and his literature also was circulating in the ideational milieu in which 4 Ezra was written. While Paul poses the plight of humanity in a unique way, it did not come out of nowhere. 


\section{Conclusion}

In summary, Sanders basically made the claim that the solution came before the plight in Paul's thinking without much support. His point that Paul saw no need for a solution before his encounter with Christ may have been true. However, the plight was certainly an assumed part of Paul's thinking and probably came from the ideational milieu of Paul's world. Furthermore, Sanders does not offer compelling arguments for his claims. These arguments grounded in Romans 7, Philippians, and Galatians are not fully developed. These texts actually demonstrate that Paul's exposition begins with an understanding of the human plight. We saw also that Sanders's delimiting of his sources may have restricted his analysis in terms of seeing the fuller picture of the ideational milieu. In particular, his bracketing of the important text 4 Ezra may be too hasty.

\section{Bibliography}

Betz, H. D. Galatians. A Commentary on Paul's Letter to the Churches in Galatia. Hermeneia. Philadelphia, PA: Fortress, 1979.

Bruce, F. F. The Epistle to the Galatians. A Commentary on the Greek Text. Grand Rapids, MI: W. B. Eerdmans, 1982.

Bultmann, Rudolf. Theology of the New Testament. Translated by Kendrick Grobel. Volume 1. London: SCM Press, 1952.

Burton, Gideon O. Siva Rhetoricae. Brigham Young University. http://humanities.byu.edu/rhetoric/ (accessed March 22, 2011).

Daube, David. "Rabbinic Methods of Interpretation and Hellenistic Rhetoric". Hebrew Union College Annual 22 (1949): 239-264.

Dunn, James D. G. The Theology of Paul the Apostle. Grand Rapids, MI: William B. Eerdmans, 1998.

. "Romans 1-8". Word Biblical Commentary. Edited by David A. Hubbard and Glenn W. Barker. Volume 38A. Dallas, TX: Word, 2002.

Helyer, Larry R. Exploring Jewish Literature of the Second Temple Period. A Guide for New Testament Students. Downers Grove, IL: InterVarsity Press, 2002.

Lane, William L. "Hebrews 1-8". Word Biblical Commentary. Edited by Glenn W. Barker, David A. Hubbard and Bruce M. Metzger. Volume 47A. Dallas, TX: Word Books, 1991. 
Longenecker, Richard N. "Galatians". Word Biblical Commentary. Edited by David A. Hubbard and Glenn W. Barker. Volume 41. Dallas, TX: Word, Incorporated, 1990.

Sanders, E. P. Paul and Palestinian Judaism. A Comparison of Patterns of Religion. First American Edition. Philadelphia, PA: Fortress Press, 1977.

Schreiner, Thomas R. "Romans". Baker Exegetical Commentary on the New Testament. Edited by Moisés Silva. Volume 6. Grand Rapids, MI: Baker Books, 1998.

Schweitzer, Albert. The Mysticism of Paul the Apostle. Translated by William Montgomery. New York, NY: The Macmillan Company, 1955.

Silva, Moisés. "Galatians". Commentary on the New Testament Use of the Old Testament. Edited by G. K. Beale and D. A. Carson, 785-812. Grand Rapids, MI: Baker Academic, 2007.

Witherington, Ben, III. Grace in Galatia. A Commentary on St. Paul's Letter to the Galatians. Grand Rapids, MI: Wm. B. Eerdmans Publishing Co, 1998. 